\title{
EL ARTE POPULAR DE RIO GRANDE DO NORTE A TRAVÉS DE LA COLECCIÓN DE NILDO FRANCINILDO SILVA \\ THE POPULAR ART OF RIO GRANDE DO NORTE THROUG THE NILDO FRANCINILDO SILVA'S COLLECTION
}

Rubén Figaredo Fernández* ESNE. Escuela Superior de Negocios

"Un hombre sólo precisa de aquello que puede cargar"

\section{Resumen}

Este artículo pretende exponer una reflexión acerca de la relación del hombre con lo trascendente a través de un arte religioso mueble de carácter popular. El ámbito geográfico es uno de los estados del Nordeste brasileño, Rio Grande do Norte, y las piezas estudiadas pertenecen a la colección del galerista local Nildo Francinildo Silva. Explicaremos algunos ejemplos de particularidades devocionales y su encarnación material en imágenes. Actualizaremos los conceptos de "popular" y "erudito", dándole voz al pueblo a través de sus artistas y creencias.

Palavras-chave: arte popular, arte erudito, Nildo Francinildo Silva, Nordeste Brasileño.

\section{Abstract}

This article is an attempt to introduce some thoughts about the relation of man and the transcendent through a kind of popular religious, portable furniture. The spatial cut-out is one of the states in North-Eastern Brazil, Rio Grande do Norte, and the studied pieces are part of the collection of the local gallery owner, Nildo Francinildo Silva. Some examples are given of devotional peculiarities and their material incarnation in images. The concepts "popular" and "erudite" get an upgrade: they give a voice to the people through their artists and believes.

Keywords: Popular Art, Erudite Art, Nildo Francinildo Silva, NorthEastern Brazil.

\footnotetext{
*E-mail: rubenfigaredo@hotmail.com
} 


\section{La colección como reordenación del mundo}

"El verdadero orden en la comunidad purifica y conserva. El verdadero orden en la soledad purifica y aumenta. La comunidad nos da calor, mientras que la soledad nos da la luz". C.G. Jung. ${ }^{1}$

Aparte de las riquezas tangibles, compuestas por dinero y bienes, existen otras riquezas intangibles que adquieren la importancia que cada poseedor quiera darles. Puede ser que para algunos esa vida rica consista en experimentar aventuras que soñó en su infancia, o materializar aquellas peripecias que ni siquiera llegaron a existir en sus mejores sueños.

En mi opinión existe una riqueza que trufa las dos calificaciones, y esa es la que disfruta el coleccionista. Por una parte el atesora bienes, pero su valor es variable y siempre discrecional dependiendo del mercado, pero sobre todo del valor que el propio acumulador siente que tiene.

Existen tantos tipos de coleccionistas como personas. Los hay que se contentan con al mínimo riesgo e invierten sobre seguro, en cuanto otros añaden al placer de la búsqueda el vértigo de la incertidumbre.

Escribir sobre arte popular ultraperiférico, calificado así por su pertenencia a un entorno geográfico alejado de los principales núcleos de población, con una escasa exposición a las corrientes culturales dominantes y a los medios de comunicación de masas, entraña otra dificultad que el investigador contumaz transforma en el placer de lo desconocido. El erudito ha de enfrentarse a las piezas sin la red de seguridad que ofrece una sólida bibliografía que facilita el trabajo de quien solo desea encarar cuestiones ya estudiadas desde otro punto de vista, o proponiendo otro discurso.

En este caso optamos por dejarnos llevar por un coleccionista y su mirada particular hacia el arte popular, como intermediarios para crear un discurso incipiente y provisional, que, huyendo determinadamente del concepto eurocentrista y paternal de "rescate" intente establecer algunas líneas que permitan el gozo estético y la comprensión intelectual de estas joyas, desconocidas para el gran público por su carácter popular y exótico, y su ausencia de adscripción en el relato del llamado arte con mayúsculas. 


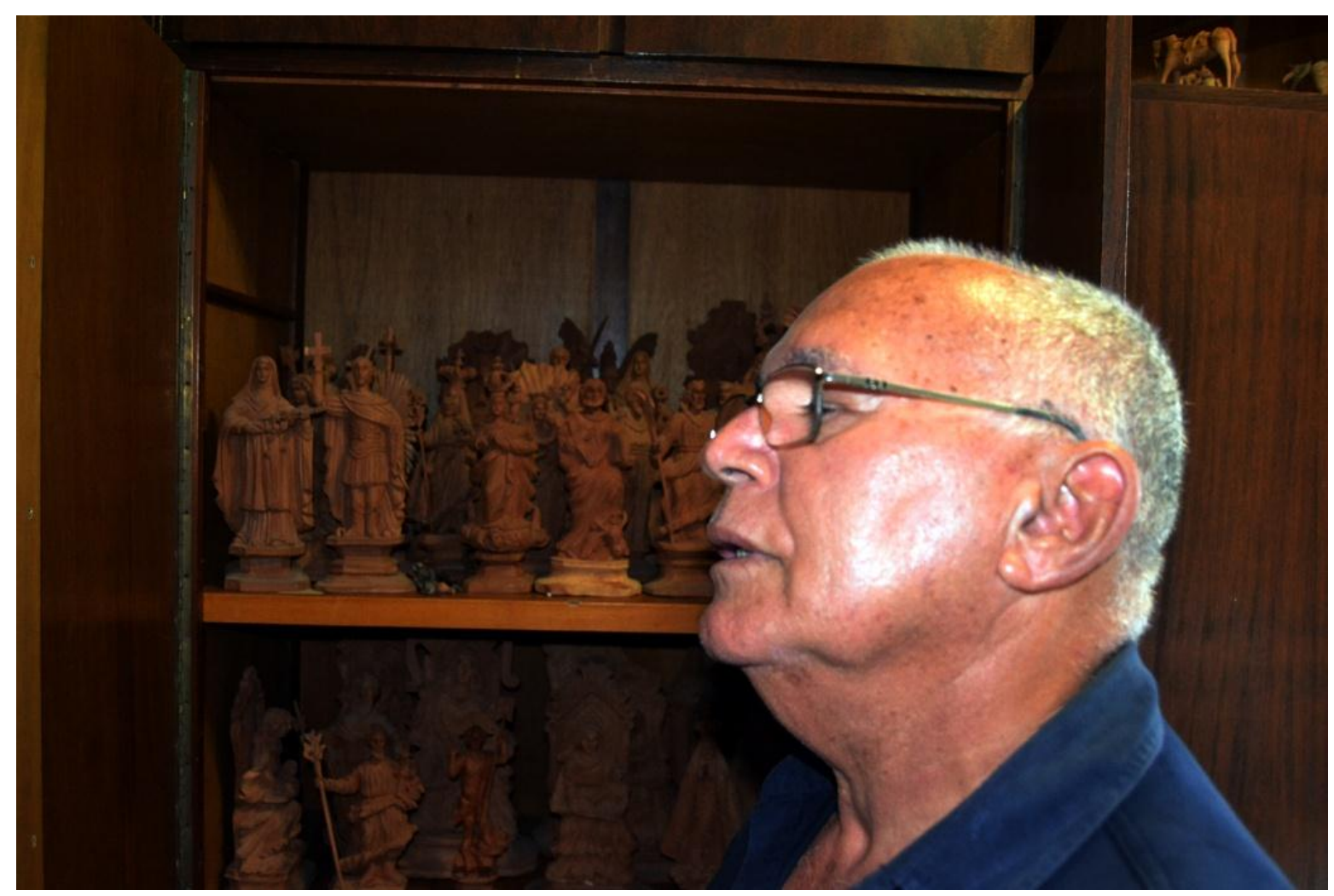

Fig. 1. Nildo Francinildo Silva frente a algunas piezas de su colección.

Como un Noé del "sertão"2 norte-riograndense, Nildo Francinildo Silva fue acumulando especies de todo tipo de arte popular, pero no sólo rescató una pareja de cada género como el personaje del Génesis. En las atiborradas estantería de su colección permanecen remesas y producciones completas de algunos de sus artistas favoritos. Contra cualquier tentación de restar valor, y contrariando las cuitas de cualquier "benjaminiano" atento a los avatares del arte en tiempo de su reproductibilidad mecánica, cada pieza igual es completamente distinta, y los descubrimientos del coleccionista ocupan casi todo el espacio disponible, en un "horror vacui" de santos y plebeyos, caballeros de armadura y cuadros de colores planos.

Las colecciones, lejos de forzadas interpretaciones que estiman el ajuar mortuorio como un acervo particular del finado, comenzaron históricamente como gabinetes de las maravillas y de maravilloso cabe adjetivar este arte popular, ayuno de academias y tratados pero lleno de encanto, e igual de milagroso que los personajes que representa, mostrando que toda necesidad de expresión, igual que el agua, acaba encontrando el camino más corto entre la emoción y la materia.

Igual que el coleccionista renacentista boloñés Aldrovandi recorría los mercados de pescado, procurando restos del pasado que pudieron quedar presos en las redes de los pescadores ${ }^{3}$, Francinildo lleva toda la vida recorriendo su estado natal buscando esos diamantes en bruto en los que la doctrina católica se mezcla con las tradiciones paganas, tendiendo lazos entre ese mundo terrestre y seco, y el incierto más allá, que en estas tierras de pocos médicos y menos 
hospitales resulta una amenaza latente por la cual más vale estar a bien con los cielos y sus criaturas.

Estos simples objetos eran, y son, un punto de intersección entre lo material y lo espiritual, una manera de atesorar sin ofender a Dios - antes glorificándolo- reverberando las hazañas de sus siervos y ministros materializados en madera de umburana. ${ }^{4}$

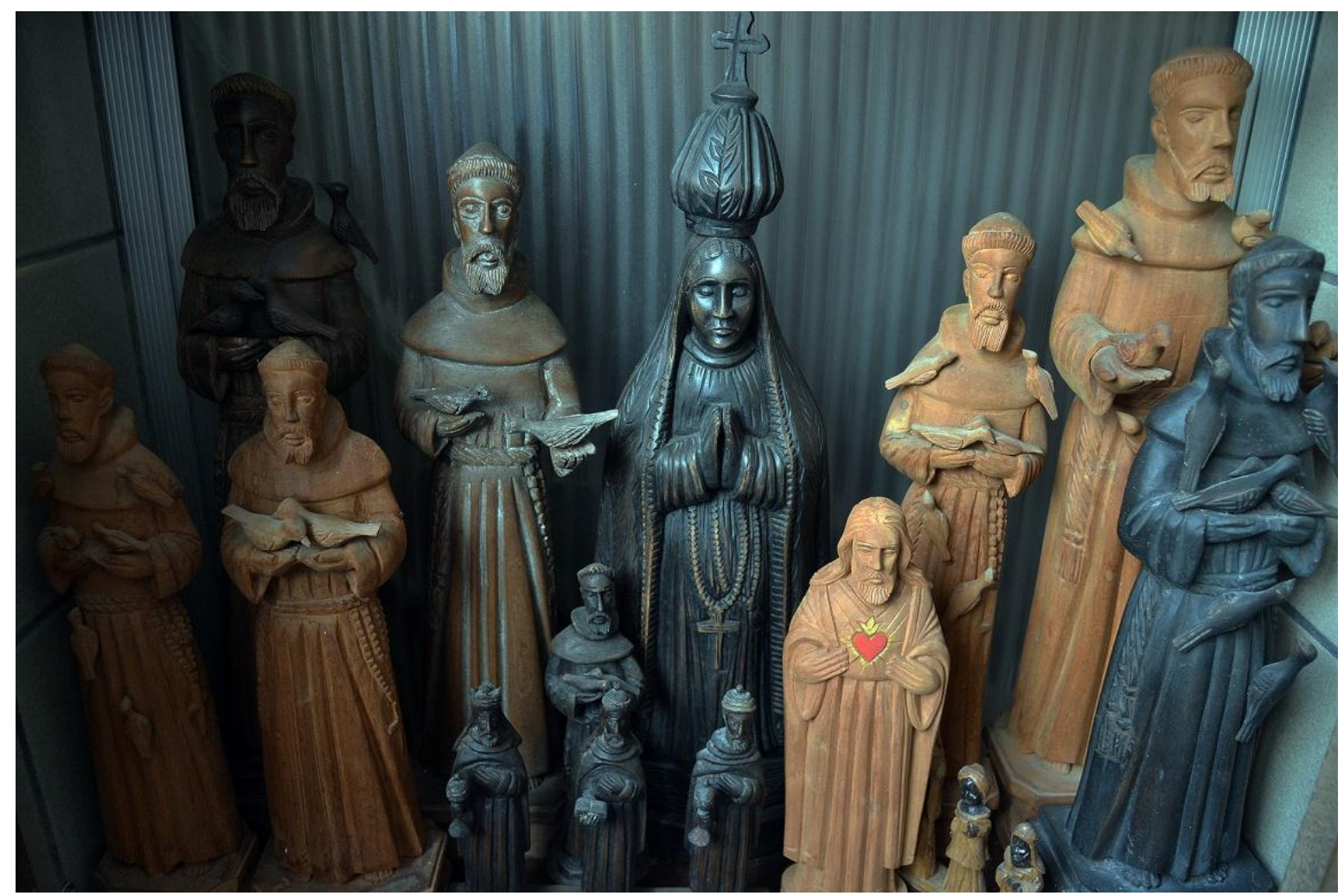

Fig. 2. Vista parcial del acervo de Francinildo, con imágenes de San Francisco de diferentes colores y tamaños, un Sagrado Corazón de Jesús, Nuestra Señora, Reyes Magos etc.

La ventaja de coleccionar piezas de fe, en las que se encarnan ideales, es que ellas no sienten el paso del tiempo. No saben de modas ni modismos, manteniendo intactas las huellas de la gracia a través del tiempo. En el caso brasileño, esta gracia no sólo es un concepto religioso, es una alegría de vivir que se trasmite hasta en las curvas y movimiento de las figuras que, manteniendo su idealización, podrían representar a cualquier vecino, envuelto en la lucha terrenal por la supervivencia, mientras mira de reojo la trascendencia.

El studiolo es una prolongación privilegiada del lar. Lo compone un menaje, una botica para el alma, en el que el hombre primordial que no sabe, se equipa con versículos revelados, relatos heroicos y anales reveladores. La fusión entre el documento y el símbolo, entre la ciencia y la creencia son las reacciones principales cuasi alquímicas que se viven en un gabinete y que jamás se podrán conseguir en ninguna pesquisa digital, saltando de acervo en acervo. 
Una cornucopia como la que posee Francinildo en estos trópicos alegres, podría hacer las veces de una puerta dimensional en la que resguardarnos del sensualismo para ser abrazados por las virtudes teologales.

Otra de las fronteras que se cruzan, visitando una colección como la que nos ocupa, es la que separa lo privado y lo íntimo de lo público y superficial.

La religiosidad popular tiene mucho de culto a los antepasados. La fe se hereda como el apellido, junto con estampas, cuadros e imágenes que van atravesando generaciones con su perfume católico y pagano.

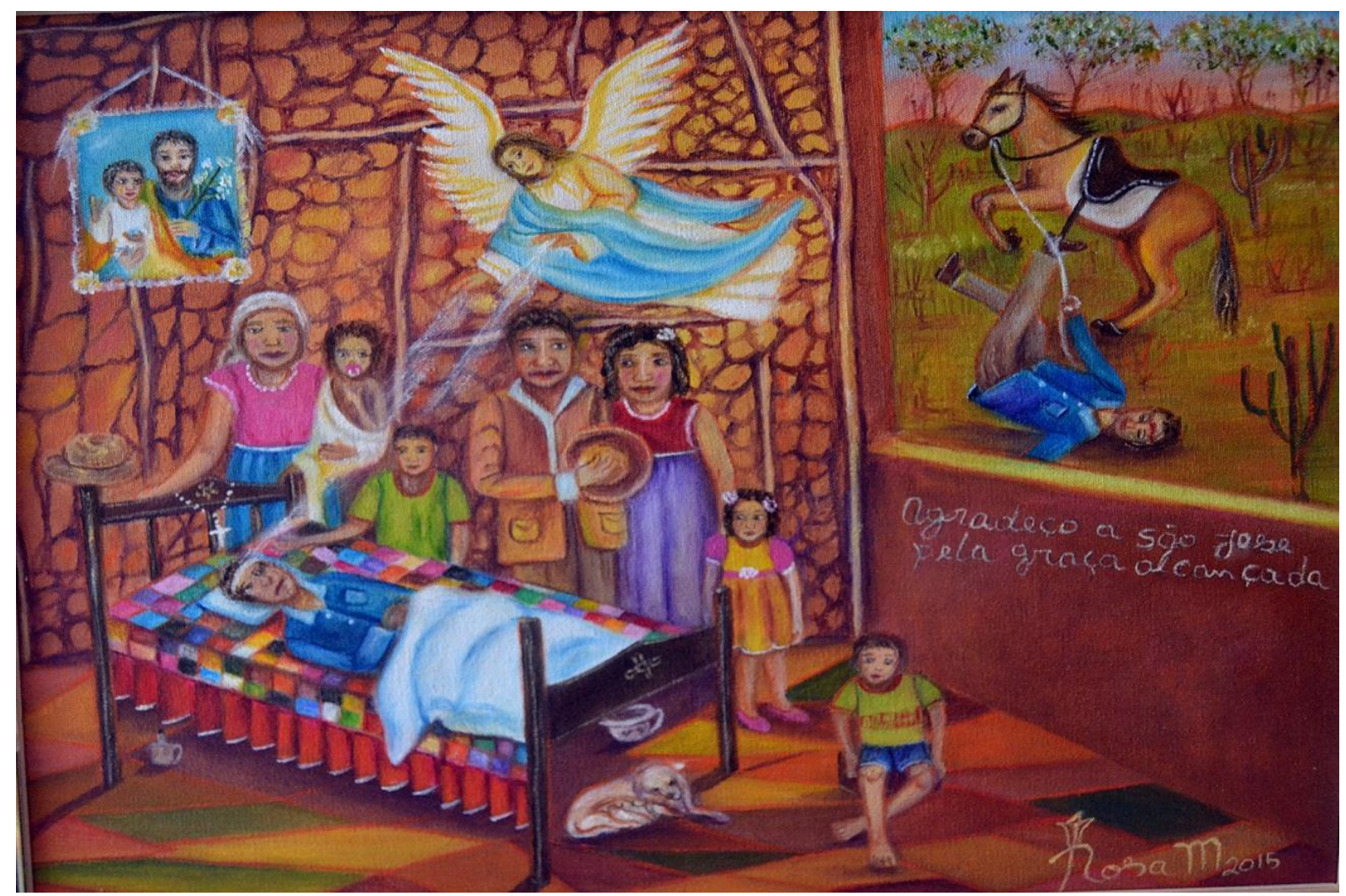

Fig. 3. Copia del ex-voto dedicado a la recuperación de Francinildo después de un accidente. Óleo sobre lienzo $50 \mathrm{X} 20 \mathrm{~cm}$.

Cuando Francinildo era joven se cayó de su caballo, como Pablo de Tarso, mientras corría detrás de los bueyes de la hacienda familiar, en la Sierra de Barriguda, un confín del estado de Rio Grande do Norte, donde da la vuelta el viento. Con heridas graves, se llegó a temer por su vida y su madre le hizo una promesa a San José: un ex-voto en forma de cuadro si su hijo se salvaba. Lógicamente este lienzo es una de las joyas de la colección ya que su existencia certifica que el ofrecimiento fue escuchado.

La promesa da vida a la materia que va marcando un posible camino de retorno, como las piedrecitas blancas del cuento de Pulgarcito de Perrault o el Hansel y Gretel de los hermanos Grimm.

Los ex-votos son las reliquias inventadas, la huella material de que un milagro se produjo sin necesidad de que la Iglesia y sus doctores lo confirmen. 
Ellos recuerdan como un fiel cualquiera ha pasado por un trance difícil y ha vencido.

Posiblemente este retazo autobiográfico fuera una de las razones por las que Nildo decidió atesorar estos objetos que reúnen la creencia y la memoria popular con las cualidades mágicas y estéticas.

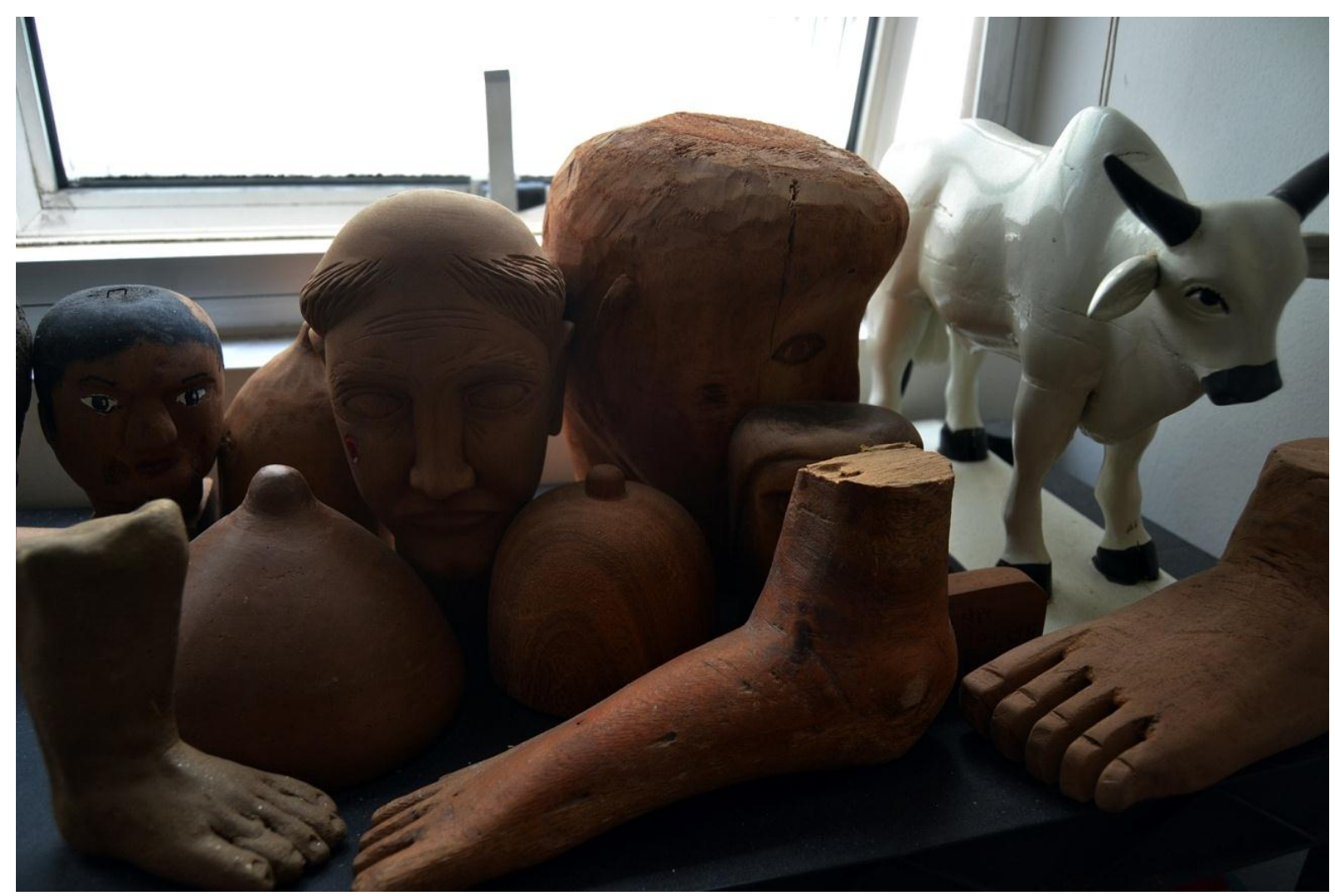

Fig. 4. Ex-votos nordestinos de autoría desconocida. Utilizados para "pagar promesas" generalmente relacionadas con la salud del comitente, se encuentran, acumulados por los devotos, en los principales templos de peregrinación del estado, en especial en los santuarios de Santa Cruz o Santa Rita.

Tal y como escribimos en otra ocasión:

"Dar a la imagen del dios la forma humana es también un intento del hombre de desembarazarse de sus males y auto-exculparse de sus equivocaciones, que atribuye a la poca ayuda prestada por el dios materializado en el icono. Orígenes afirmaba que la verdadera imagen de Dios se lleva en el corazón y que llegar a él era un cometido que solo la envoltura material que cubre nuestra alma podía impedir". 5

El creador es menos definido y definible que la creación, y en los pliegues y recovecos de esa indefinición el arte popular filtra su imaginario. 
"Al mismo tiempo, esos objetos han cobrado nueva vida como parte de un organismo, de la imagen especular del coleccionista; ahora son entidades que plantean nuevas demandas a la vida del coleccionista y que crean sus propias leyes, emanan su propio poder. Como las reliquias, están muertos, y sin embargo muy vivos en la mente del creyente, del coleccionista, del devoto, y como tales forman un puente entre nuestro mundo limitado y otro infinitamente más rico, el de la historia del arte, un mundo de carisma o de santidad, un mundo de máxima autenticidad $\mathrm{y}$, por tanto, una utopía profundamente romántica. Gracias a ellos el coleccionista puede seguir viviendo aun después de que su vida termine, y la colección se convierte en un baluarte contra la mortalidad" 6 .

Tal como explicó Tillich -y vienen experimentando todas aquellas comunidades carismáticas que hayan conseguido algún éxito en sus intentos de renovación- cuando las personas dejan de experimentar lo divino, se ven obligadas a creer, y posiblemente el fruto de la creencia sincera acabará trayendo consigo la experiencia de Dios.

Asimismo, en opinión de Hoeller, "el sentido interno de Dios es una cualidad de la psique profunda y no de la razón. (...) Cuando Occidente quedó perdido para la interioridad espiritual, lo único que quedó fue la creencia, o el eufemismo religioso que la sustituye, la fe".7

En el caso de Brasil, el discurso tiende a sustituir cada vez más el rito, y el misticismo tiende a perderse:

"El vacío que se abre entre el creyente y lo sagrado aumenta en la misma proporción en la que la institución se burocratiza y aumentan el número de exégetas y especialistas. En ese momento aparece un sentimiento parecido a la orfandad entre los fieles que explota en forma de movimiento sectario de recuperación de lo sagrado en su estado de pureza primitiva". ${ }^{8}$

Cuando intentamos interpretar la religiosidad de las comunidades ultraperiféricas no debemos olvidar que cuanto más grande es el peligro más necesario es Dios. El riesgo de muerte es una catarsis bastante probable a lo largo de la vida del sujeto. Este peligro, siempre presente, empuja al sujeto a situaciones místicas bastante difíciles de obtener por medios menos traumáticos.

\section{La divinización de los vivos: el caso del Padre Cícero}

En un país que tiene como acontecimiento seminal la llegada de los europeos del otro lado del océano, la flota de Cabral fue el cigoto cristiano que 
vino a convertir el óvulo indígena, liberado en este momento de culpas y lastres espirituales. En la infancia de las naciones, recién emancipadas del yugo colonial, es un fenómeno común la aparición de figuras mesiánicas que pretenden llevar al pueblo de la mano en el intento de mejorar la vida de aquellos que no cuentan nada en la vida oficial ni en la política. En el juego de voces que componen el ser brasileño parece que es imprescindible prometer el paraíso para que el pueblo olvide que ya vive en él. La diferencia entre vivir en un paraíso tropical o en un infierno verde depende de la suerte que se tiene al nacer, y esta realidad cuando los canales de participación del pueblo en la política están manipulados por los "coroneles"9 no deja a la población otra salida que explorar la vía milagrosa, esperando un mesías espiritual o de carne y hueso, para que los redima. El hecho de que el pueblo estuviera cercado por explotadores, atendiendo a su propio lucro e intereses, convierte a prácticamente cualquier personaje carismático en redentor. Si es posible que unos hombres-dioses venidos del mar muden la historia no resulta descabellado creer en que el rey Sebastião, desaparecido en combate en la batalla de Alquezarquivir, regresara al lugar en el que nunca estuvo, la primitiva Santa Cruz, nombre original de Brasil, con la intención de resolver los entuertos y las injusticias que subyugan al pueblo.
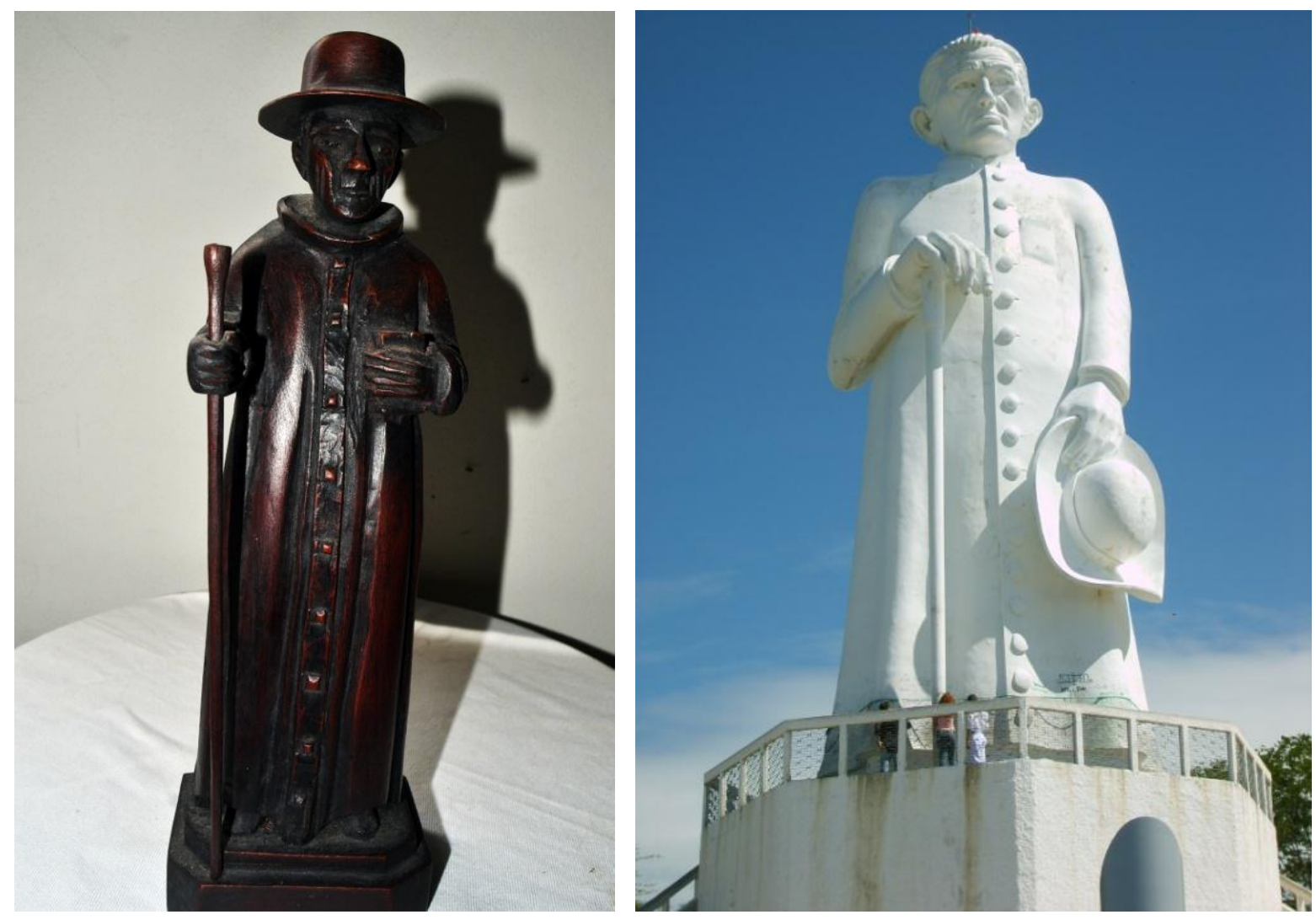

Figs. 5-6. Imagen del Padre Cícero por Luzia Dantas, $18 \mathrm{~cm}$, madera de umburana. Estatua del mismo en su santuario de Juazeiro do Norte. Esta pieza colosal de hormigón de 27 metros, inaugurada en 1969 se debe al escultor Armando Lacerda. 
Siguiendo esa estela mesiánica, el padre Cícero fue un líder carismático que dominó durante toda su vida la escena política y espiritual de su estado natal, Ceará. A los veintiocho años tuvo sus primeras visiones místicas mientras inflamaba a sus parroquianos con sermones brillantes e incendiarios, con un carácter social pero altamente paternalista, prometiendo prosperidad a los campesinos hambrientos, víctimas de sequías perpetuas que les obligaban a emigrar con lo puesto. En 1889 se registró un supuesto milagro, cuando la hostia consagrada depositada en la boca de la monja María de Araújo, se convirtió en sangre. A pesar de ser elegido diputado, nunca llegó a ejercer, dando mucho que hablar su relación con el bandido Virgulino Ferreira da Silva, "Lampião", considerado una especie de Robin Hood del sertão y muy devoto del sacerdote que le aconsejó abandonar su vida de delincuente para participar en partidas organizadas que combatieran la amenaza comunista de la Columna Prestes. Al mando de esta guerrilla estaba el capitán Luís Carlos Prestes, otro personaje mesiánico conocido con el sobrenombre de "Caballero de la Esperanza" y que en 1926 recorría Brasil cuestionando el gobierno autoritario de Getúlio Vargas.

\section{La paganización de los santos: el São Jorge brasileño}

"Lo que hagáis al más pequeño de mis hermanos, a mí me lo hacéis". (Mt 25,40).

San Jorge nació en la Capadocia en el año 280 y murió en Roma, decapitado, por orden del emperador Diocleciano por el "crimen" de declararse cristiano. Su ejecución tuvo lugar en el año 303, tenía solo 23. Sin duda, la más conocida de las hazañas del santo guerrero es la que describe su combate con un dragón, elaborada en el S.XIII por el dominicano Jacoppo Varazze, que pasó a engrosar la "Leyenda Aúrea" y de la que existen diferentes versiones con algunas variantes. Para Lévi-Strauss "no existe una versión 'verdadera', a partir de la cual todas serían copias o ecos deformados, todas las versiones pertenecen al mito". 10

A diferencia del San Jorge inglés, modelo del catolicismo guerrero medieval británico, patrón de la Familia Real inglesa - que rescata una princesa que estaba presa por el dragón después de lo cual la recibe en casamiento en medio de la aclamación popular - el San Jorge brasileño ya llega al continente americano sincretizado, producto de la yuxtaposición, asimilación y fusión de diferentes arquetipos, héroes y semi-dioses. En él se reúnen Constantino, el dios ecuestre egipcio Horus, así como se contagia de mitos como el de Perseo y Osiris, sirviendo como encarnación de los ideales de las Órdenes de Caballería ${ }^{11}$, que serían incluso la base, poco reconocida, de la religión islámica. En opinión de María Machado: "para los cristianos de Oriente él era el médico que les resguardaba contra las pestes, lepra y sífilis, así como el protector para los buenos negocios"12 

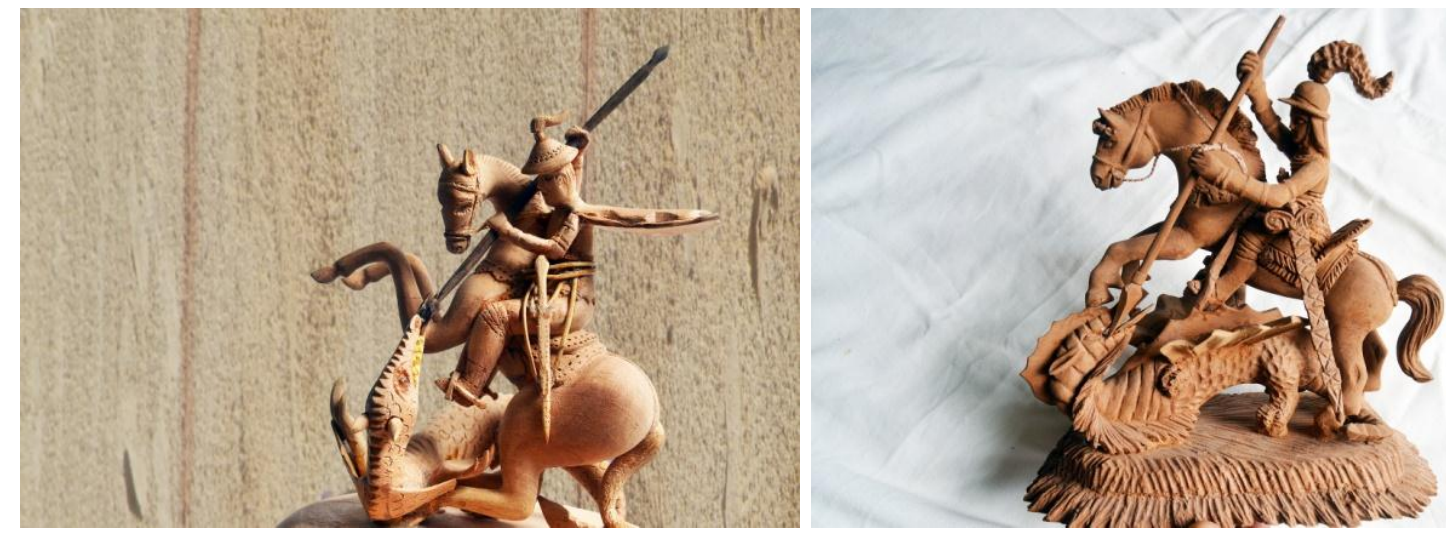

Fig. 6-7. Imágenes de San Jorge talladas por Luzia Dantas y Mestre Ambrosio de Córdula, 15 cm, madera de umburana.

Frente a los mártires que se ofrecían pasivos al verdugo en nombre de la fe, el santo capadocio propone la resistencia activa y el combate resuelto contra los enemigos de la religión cristiana. En el caso de Brasil, tanto representaba a los mantenedores del orden establecido, hidalgos y colonizadores de estirpe europea que subyugaban y desbravaban una tierra inmensa y hostil, como a los esclavos negros practicantes de "capoeira", disconformes con el poder y el estado de cosas, que se inspiraban en la capacidad de lucha del santo caballero. ${ }^{13}$

San Jorge sería una "voz" en la forma en la que Paul Zumthor define la concretización de lo inefable cuando es capaz de materializarse

La figura de São Jorge es un hilo que une diferentes culturas, razas y religiones, encarnando por sí solo un vigoroso arquetipo del inconsciente colectivo junguiano. En Brasil su culto experimenta una hibridización entre el santo de la Capadocia y los "hijos de santo" que le quitan la armadura y lo convierten en Ogun.

El santo cristiano resultaba muy conveniente para los tiempos en que la fe se expandía a sangre y fuego. Para Le Goff la victoria sobre un dragón significa algo más que derrotar al mal. Derrotar al dragón representaba la civilización y demarcación simbólica. A veces la ocupación física era lo menos importante, lo esencial era extender nuevos significados simbólicos que fueran suficientemente potentes como para convertir los patrones indígenas en elementos subalternos.

El papel de São Jorge como caballero merece un estudio aparte. Su carácter de guerrero itinerante lo convierte en una vanguardia, sin domicilio fijo, de los poderes férreos del clero y la nobleza.

\section{El arte popular, un proceso ininterrumpido}

"El objeto más importante de una colección es el siguiente". ${ }^{14}$

a. El arte popular como espacio de resistencia de la religiosidad carismática frente a la burocrática

El arte sagrado popular ejemplifica como pocos la dicotomía entre la religiosidad carismática y la burocrática. El teólogo brasileño Leonardo Boff 
abunda en esta división, estableciendo la diferencia entre los conceptos de "movimiento" e "institución". Para el jesuita, los movimientos emergen como una "autopoiesis"15 en momentos en los que el equilibrio se encuentra ausente, predominando la crisis y el caos, lo que provoca que una serie de individuos carismáticos propongan una nueva ordenación de ese caos, siguiendo nuevas reglas, o exhumando algunos modos que cayeron en el olvido con una pasión renovada que se apoya en los símbolos como elementos aglutinantes.

"La participación viene de abajo, todos se sienten envueltos, todos discuten, todos son oídos y el consenso emerge espontáneamente. Existe una gran generosidad de todos. Se crea el movimiento. Él posee un mínimo de organización, fluida, sin embargo los puntos de referencia valorativa, preceptos y leyes son seguidas por todos. El movimiento presenta una alternativa al 'establishment'. Es la cuestión fundamental que explica su aspecto libertario e revolucionario.

Pero el movimiento, cuando consigue triunfar e imponerse, muda de naturaleza. Se convierte en institución. Y con la institución entra la repetición, la rutina, la burocracia, la norma, la jerarquía de poderes". ${ }^{16}$

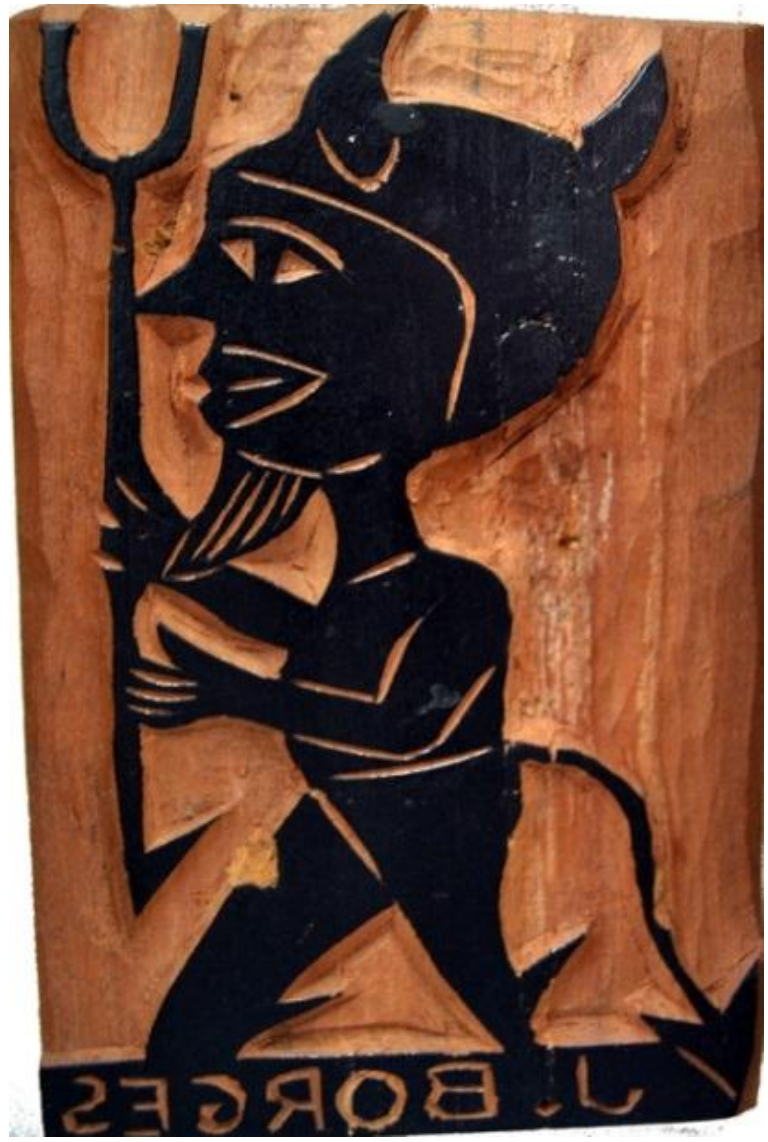

Fig. 8. Plancha de xilografía de José Francisco Borges representando al diablo. $10 \times 6 \mathrm{~cm}$, madera de umburana. J. Borges es uno de los artistas populares más reconocidos del Nordeste Brasileño. A los ocho años ya trabajaba la tierra, a los diez ya fabricaba y vendía en la feria cucharas de madera. También fabricaba y vendía juguetes de madera y pliegos de cordel. Fue a esta actividad de poeta de cordeles a la que decidió dedicarse a pesar de haber frecuentado la escuela tan solo diez meses. Como no tenía dinero para pagar un ilustrador él mismo se puso a fabricar las xilografías. En los 70 realizó la portada del libro "Las palabras andantes" de Eduardo Galeano y fue descubierto por los marchantes y coleccionistas. Cuando comenzó a elaborar matrices de mayor tamaño, disociadas del mundo del cordel, se abrió a nuevos mercados, exponiendo en Europa y los Estados Unidos. Cansado del blanco y negro, ideó una técnica para colorear los grabados. A la pregunta de cómo se arreglaba en sus viajes al extranjero hablando sólo portugués, Borges contestó: "Soy pueblerino, pero no soy burro". ${ }^{17}$ 
b. El dualismo bien/mal como herramienta de la fe

Tal y como enseña la teología, los sacramentos de la Iglesia incorporan tanto una dimensión simbólica como diabólica. El esfuerzo litúrgico nunca será terminar con esa tensión sino aprovecharla. Las historias en las que luchan los opuestos tienen una fuerza y un interés que engancha al creyente, que tanto está obligado a abrazar los dogmas como a renunciar al influjo del maligno. Lo diabólico está tan engarzado con lo simbólico que lo refuerza e incluso lo sustenta, lo único que hay que vigilar es que lo diabólico no se hegemónico.

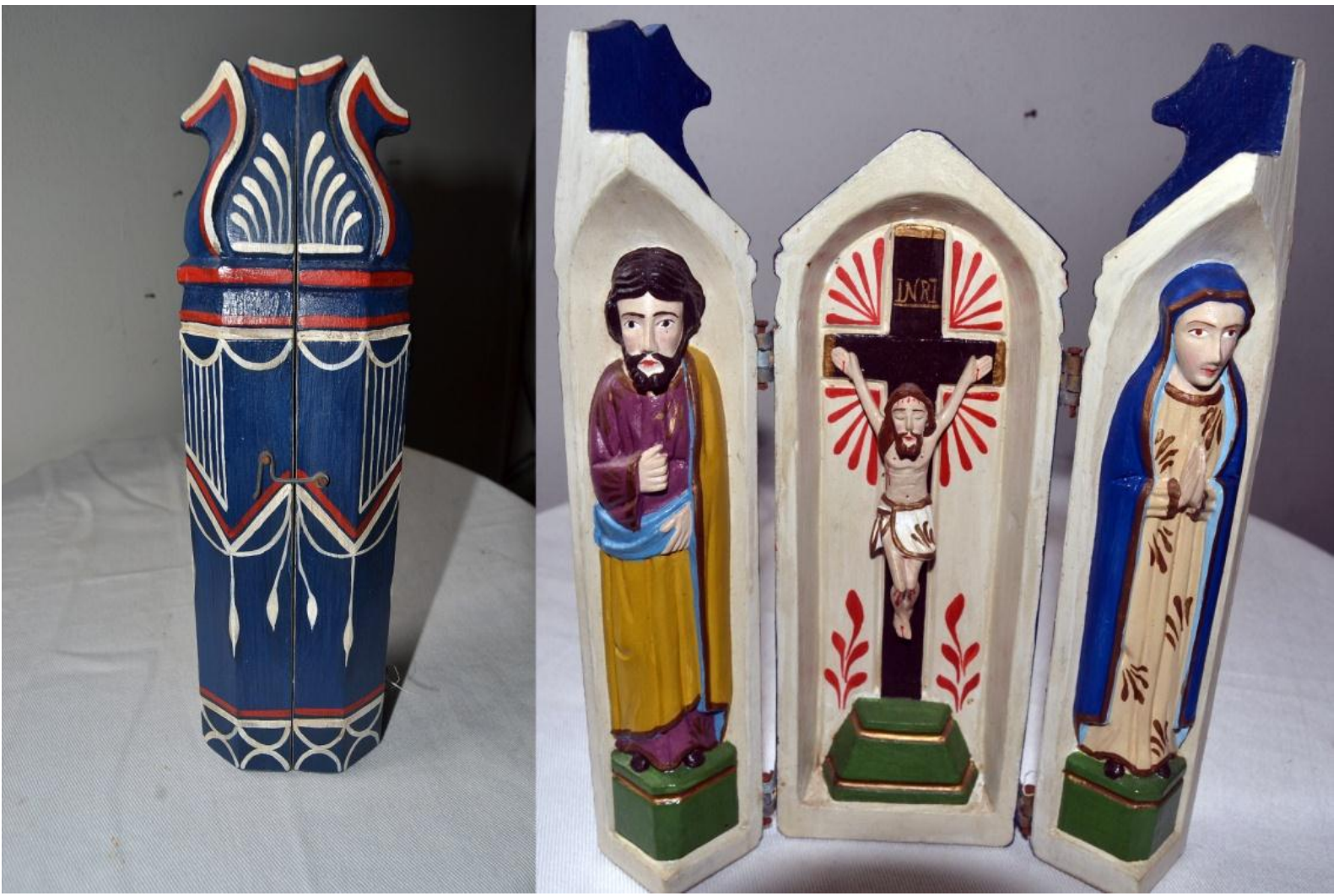

Fig. 9. Altar portátil, obra del Mestre Ambrosio de Córdula, $20 \mathrm{~cm}$, madera de umburana.

George Steiner en Nostalgia del Absoluto explica por qué es útil establecer un correlato negativo en todo sistema total de creencia:

"Un sistema total, una explicación total, se derrumba en el momento en que puede surgir una excepción importante, un contraejemplo realmente poderoso. (...) La construcción se desploma a menos que sea un todo. Si cualquiera de los misterios centrales, misterios sacramentales, del cristianismo o de la vida de Cristo o su mensaje fueran totalmente refutados, de nada serviría tratar de hacer una rápida tarea de reparación en un rincón de la estructura"18. 
Esta es una de las razones por las cuales es tan importante integrar lo demoníaco en la liturgia, en el papel del enemigo acechante que está siempre dispuesto a hacer el mal, eso sí, con cuidado de que cada creyente no lo identifique dentro de sí porque esto dejaría sin función definida a los ministros, encargados del pastoreo de las almas.

Sin embargo, el conocimiento de algunos de los trucos del prestidigitador no impide que echemos en falta la magia ni que sintamos nostalgia de lo inefable:

"Esta nostalgia, tan profunda, yo creo, en la mayor parte de nosotros, fue directamente provocada por la decadencia del hombre y la sociedad occidental, por la decadencia de la antigua y magnífica arquitectura de la certeza religiosa. (...) tenemos hambre de mitos, de explicaciones totales, y anhelamos profundamente una profecía con garantías"19.

En el Renacimiento, la Iglesia fue muy astuta al reprobar a Galileo, a sabiendas de que tras los nuevos descubrimientos astronómicos vendrían más y acabarían poniendo en solfa el monopolio de la verdad que la Iglesia reclama para sí.

Quizás habría que acotar los significados de los simbólico y lo diabólico. Lo simbólico tiene su origen en el griego clásico. Sim-bolo/sim-bólico proviene de symbállein o symbállesthai. Literalmente significa: lanzar (bállein) junto (syn). El sentido sería: lanzar las cosas de tal forma que ellas permanezcan juntas, reuniendo realidades distintas. Diabólico, sin embargo, proviene de dia-bállein que significa literalmente: lanzar cosas para lejos, de forma desagregada y sin dirección; arrojar cosas de cualquier manera. Dia-bólico, como se ve, es el opuesto de sim-bólico. Es todo aquello que desconcierta, desune, separa y opone. ${ }^{20}$

Tal y como afirma Leonardo Boff, el ser humano posee también esa misma polarización diabólica/simbólica, es a un tiempo sapiens y demens. Posee una inteligencia capaz de proyectar y armonizar pero también de practicar la violencia, el desvarío y la impiedad. La discriminación y comprensión de la relación dialéctica entre lo diabólico y lo simbólico no depende solo de la razón, incluso podríamos decir que es una relación ajena a ella, dependiendo su aprehensión de capacidades poco apreciadas por la academia y el mundo erudito, tales como la intuición, la empatía o el corazón. Estas relaciones incluso pueden conformarse como "misterios", cruce de dimensiones que, como las líneas paralelas, solo se unen en el infinito, en la eternidad.

George Steiner nos exhorta para abandonar "la orgullosa imagen del "Homo Sapiens' - el hombre conocedor, el hombre a la caza del conocimiento - y pasar a esa visión encantadora del 'Homo Ludens', que significa sencillamente el hombre que juega, el hombre relajado, intuitivo, el ser pastoril". ${ }^{21}$

Ya que no le suponemos al pueblo brasileño, mayoritariamente iletrado, una cultura libresca, habremos de concederle la gracia de la empatía y la intuición, capacidades imprescindibles no solamente para la vida sagrada sino también para la profana. 
A este respecto se refiere Steiner cuando dice que: "La lógica es el arma de la burocracia culta contra los modos intuitivos y sensoriales de decir y sentir de las masas menos cultas. El colocar en un templo las leyes científicas, sean newtonianas, darwinianas o malthusianas, refleja una implicación consciente en el control intelectual y tecnológico sobre la sociedad". ${ }^{22}$

c. El contraste de los cánones de lo popular y lo erudito. La belleza de lo compartido

La Física Cuántica, tal y como la gramática, existió mucho antes de que fuera descrita. Lo popular existe sin que precise ser relatado por la academia, necesitando únicamente un escrutinio externo para dar cuenta de su curso y facilitar su fluidez, igual que una determinada pendiente favorece el discurrir de un río en su naciente.

Bacarelli sostiene que el concepto de las "Bellas Artes" no existía en las sociedades primitivas en las que todas las artes privilegiaban el uso antes de la estética, defiende que el arte era apreciado por su practicidad, por la idoneidad de su diseño para servir a la función para la cual fueron creadas, y no por su belleza formal. ${ }^{23}$ Nosotros disentimos, ya que es imposible hablar de belleza en tiempos en que no existía tal concepto, ni siquiera un canon comúnmente aceptado sobre aquello que es hermoso. La belleza precisa un tiempo de reposo, responde a una construcción cultural que selecciona entre los modelos disponibles aquellos que responden a unas ciertas calidades o proporciones tenidas por apropiadas en un determinado momento y en un lugar dado. Hablar de belleza en el arte popular es como insinuar que en un coro o en un grupo de baile primitivo hubiera espacio para una calificación positiva de los artífices, cantantes o danzarines, en función de su mayor o menor capacidad para afinar o su destreza a la hora de repetir en sincronía con el grupo unos determinados pasos de baile.

Generalmente reconocemos el arte popular por una serie de características como son: la condición de autodidactas de los artistas, su apoyo en las formas de la tradición oral y la memoria, y por último la escasa importancia económica de su actividad que han de simultanear con otros oficios u ocupaciones para completar sus emolumentos.

En el caso del arte sagrado popular, podemos afinar más las diferencias echando mano de un historiador de las religiones como Jean Delumeau que se percata de la folclorización de las religiones y apunta las diferencias entre la religión dogmática y la religión vivida. 

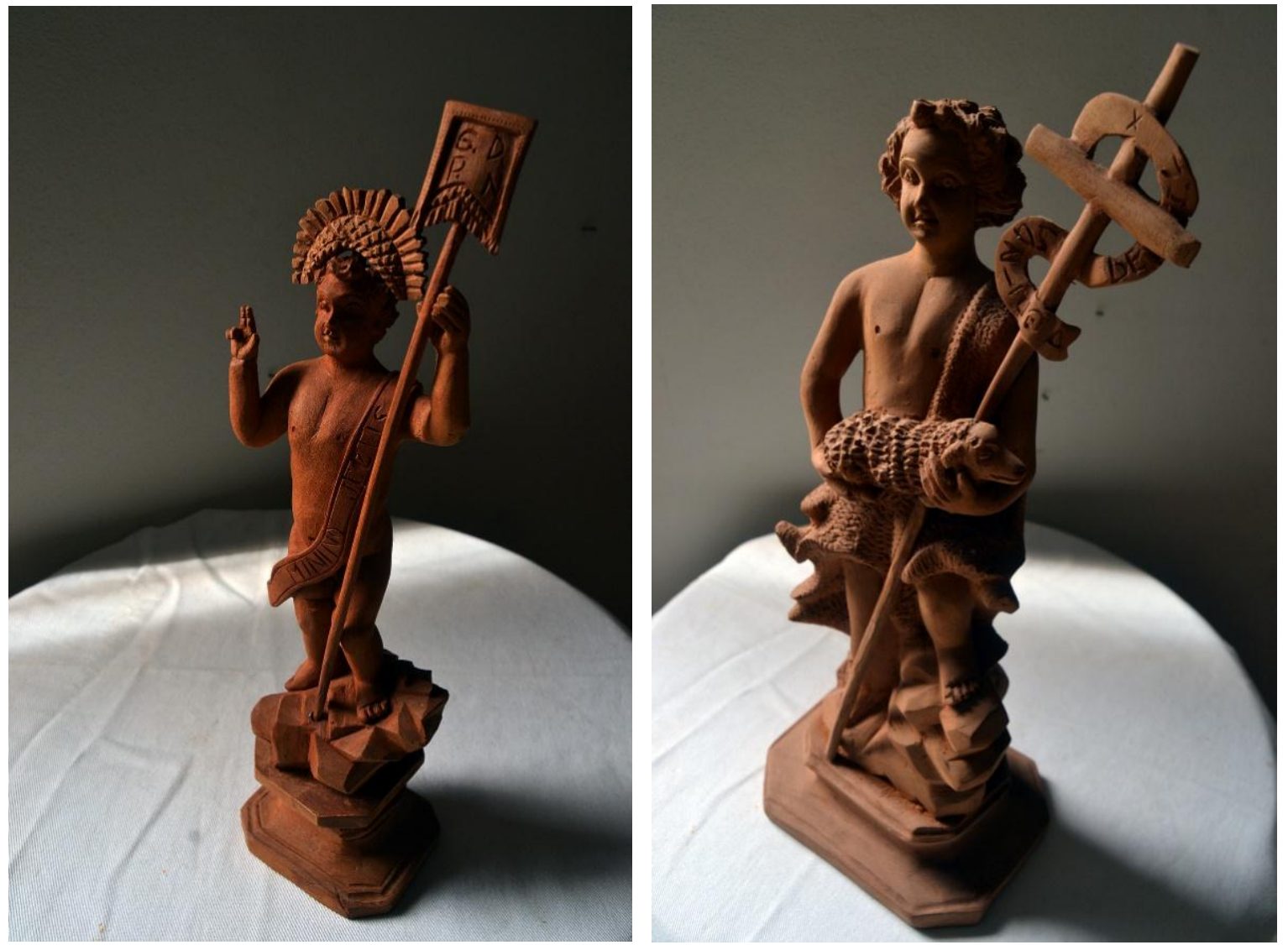

Fig. 10-11. El Niño Jesús y San Juan niño de Luzia Dantas, 18 y 24 cm. respectivamente, madera de umburana.

Para el experto brasileño Emanoel Araújo, en el arte popular brasileño se pueden distinguir tres características principales, no excluyentes entre sí:

Arcaísmo: Afecta principalmente a grupos sociales aislados del sertão, inmunes a las influencias modernizadoras de las grandes ciudades y las poblaciones de costa. El sustrato de este arcaísmo tiene raíz africana y europea, la matriz africana repite patrones de las sociedades ancestrales teocéntricas; la raíz europea proviene, como no puede ser de otra manera, de los colonizadores y evangelizadores de este continente con las costumbres importadas de las sociedades medievales ibéricas. Ejemplos característicos de este arcaísmo son los ex-votos en barro y madera, las barcas de San Francisco y las imágenes de santos setecentistas, caracterizados por su actitud hierática, su frontalidad, y una sensación de soberanía, poder y soledad. Son figuras humanas y divinas a la vez, ejerciendo de mediadores entre cielo y tierra.

Ancestralidad: Los "ancestrales" aparecen en el imaginario del artista popular como inspiradores de su arte, descargando su propio mérito como creadores en los hombros de las generaciones precedentes, responsabilizándolas de su intuición. Su arte bebe directamente en la herencia cultural, la tradición oral y el inconsciente colectivo.

Permanencia: La persistencia en el tiempo y en el espacio de ciertas manifestaciones de arte popular se apoya en los ciclos festivos correspondientes a las faenas agrícolas, las onomásticas de los santos, carnavales, ferias y mercados, 
en los que siempre hay un lugar para mostrar los productos de la creatividad popular. ${ }^{24}$

La paradoja es que nada se define a partir del objeto, el artífice o su contexto, sino desde la tiranía ilustrada de los ojos que miran, con toda su carga de prejuicios, manías personales y tics aprendidos. Si calificamos un determinado arte por su poso, por el tiempo de maduración de sus formas y modos de hacer, muchos de estos artes populares merecerían ser tildados de cultos por sí mismos, sin definirlos por comparación con otros mejor conocidos y valorados por la academia. Llámese pereza intelectual o fobia al riesgo, los prefijos pre y post vienen sustituyendo a otras etiquetas más elaboradas intelectualmente. Ese tedio viene abonado por un mundo que paulatinamente va dando la espalda a unas humanidades que parecen no darse por enteradas y prefieren perpetuarse en discusiones bizantinas y peleas de egos en vez de entrar de hoz y coz en la sociedad dejando atrás plumas, afeites y libreas propias del pontificado. Parece que pocas cosas han cambiado desde que Giulio Carlo Argán y G. Cocchiara definieran en 1963 el arte popular como "arte provinciano" 25 , como si las capitales tuvieran otro arte que el que son capaces de comprar, y el arte culto no fuera tan a menudo más provinciano que el más humilde objeto creado a solas por un individuo iletrado, sin otros artificios que su conocimiento de la materia, destreza y creatividad. En este juego pugnan aquellos que heredaron saberes y quienes solo heredaron prejuicios.

Si estuviéramos condenados, como insinuó Leví-Strauss, afirmando que la antropología culminará en "entropología", o ciencia de la entropía y la extinción²6, podríamos tomar para nosotros, historiadores del arte, el papel de guardianes de lo que quedó, tutores de los restos de un naufragio o de un incendio del cual los antropólogos hablarán leyendo sus cenizas.

\section{d. Arte popular y política}

Por otra parte, el bando de los defensores de lo "popular" no está exento de intereses espurios y manipulaciones interesadas. La cultura autóctona siempre fue ninguneada por los colonizadores con la excepción de aquellos casos en los que su conocimiento y utilización fueran provechosos para los planes evangelizadores o aculturizadores de la metrópolis. En el caso brasileño conviene recordar que el primer libro escrito en la lengua vernácula tupí-guaraní fue un catecismo escrito por el padre Jesuita José de Anchieta.

Por otro lado, en el campo de la política existe una marcada intención paternalista en el concepto de "rescate" empleado por muchos personajes de la izquierda, mientras que a la derecha del abanico político lo que predomina es el intento de instrumentalización de los artistas populares como poseedores de una parte de las esencias nacionales que es preciso preservar y glorificar como forma de resguardarse de las perniciosas influencias foráneas. El gusto por el arcaísmo de las estructuras coloniales es una forma de retroversión histórica que "apareció para confirmar, sobre un escenario global moderno, concepciones antiguas del poder y el privilegio" 27 . 

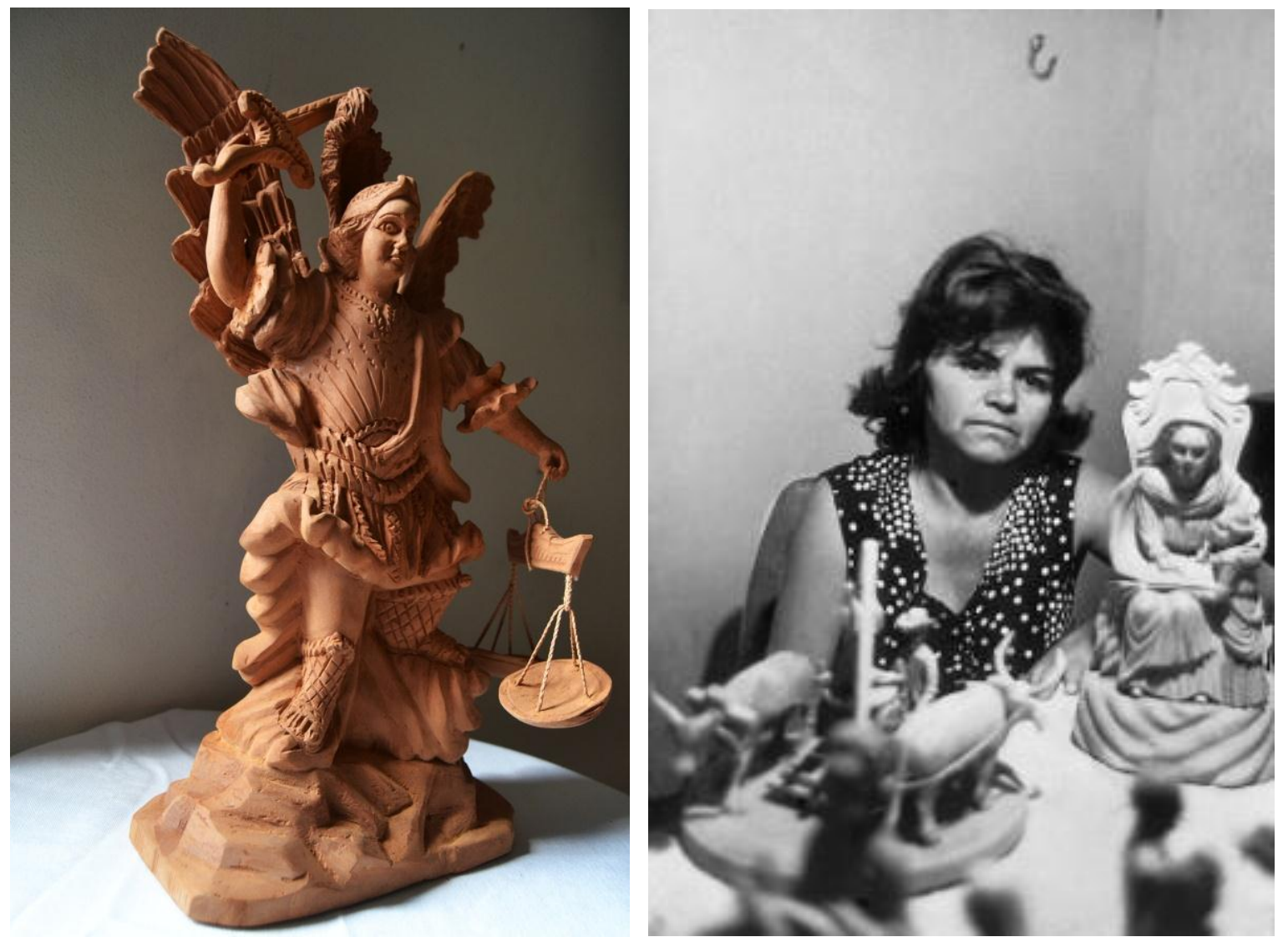

Fig. 11-12. El Arcángel San Miguel de Luzia Dantas (24 cm.madera de umburana) y la propia autora. Doña Luzia nació en 1937 en un pueblecito perdido en el interior norteriograndense. Jamás recibió clases ni contactó con cualquier otro artista popular. Su estilo barroquizante es absolutamente autodidacta. Comenzó a tallar madera siendo niña, como un juego, y todavía no ha parado. Sus piezas viajan ahora a todo el mundo desde su modesto taller en la pequeña ciudad de Currais Novos. Para los rostros se inspira en las facciones de amigos, conocidos o familiares, incluso pide fotos de los comitentes para copiar sus rasgos.

Para el estudioso del arte y el artista culto, existe otra maniobra interesada de acercamiento a lo popular que comienza en el Romanticismo y que en palabras de Bernard Lamblin buscaba sintonizar con un mundo rural "que guardaba el perfume del Jardín del Edén"28. Se relacionaba entonces el campo como un espacio para las verdades eternas en el que se desarrolla una relación directa entre los individuos y la naturaleza. 


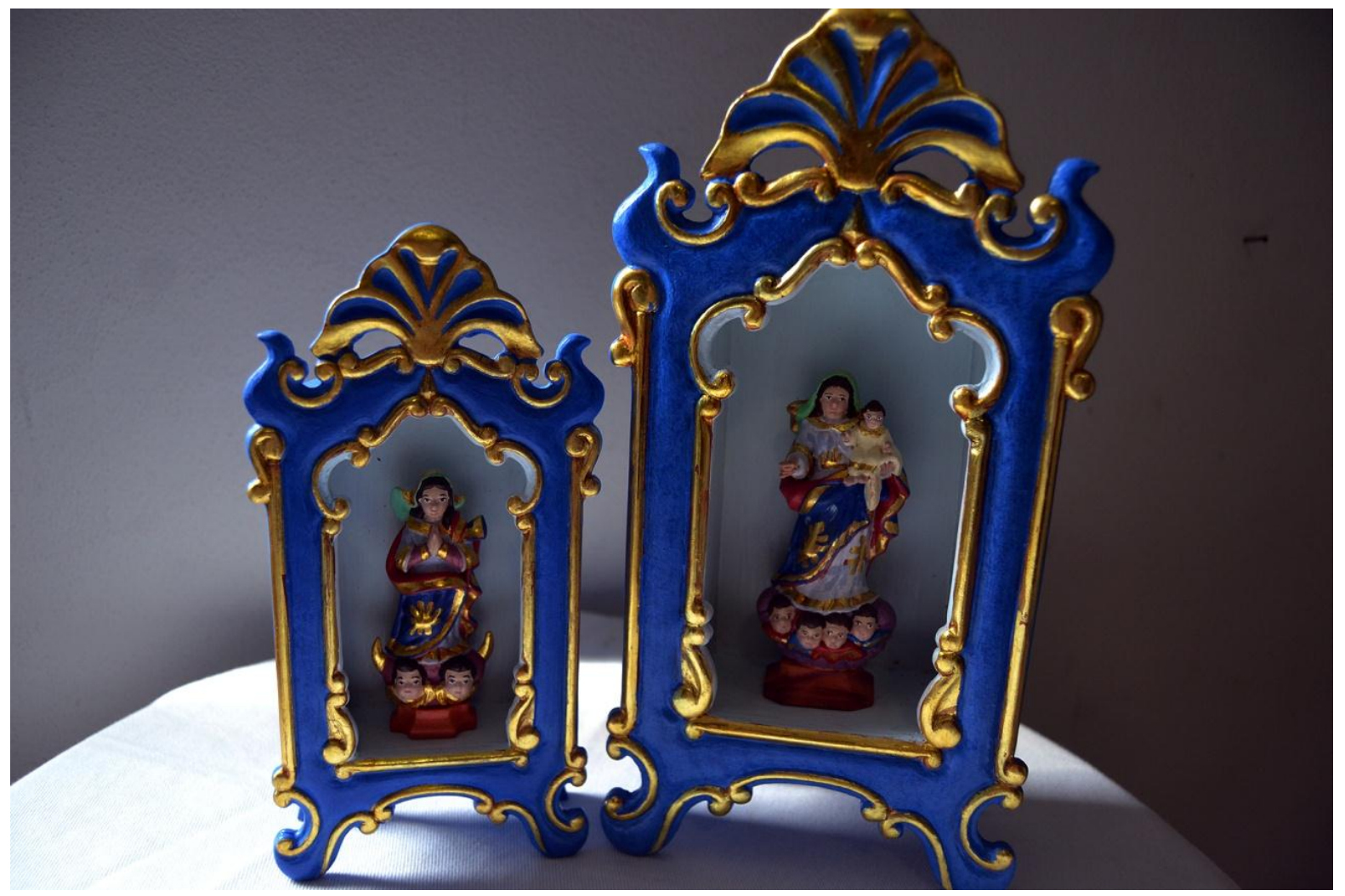

Fig. 13. Réplica en miniatura de Nuestra Señora de los Imposibles, 12X6 y 16X8 cm. respectivamente, madera de umburana, ubicada en el Santuario de Patu, obra del Mestre Ambrosio de Córdula.

Este mito del "primitivismo" se asentaba en los ideales ilusorios de simplicidad, trabajo virtuoso e inocencia. Una Arcadia intemporal inventada en la que los hombres no habían tenido aún la oportunidad de corromperse, ligados a la tradición y ajenos al individualismo y el materialismo. Ayer, como hoy, los que mandan imitan las virtudes de los que obedecen para cubrir su despotismo con un camuflaje para cada ocasión. 


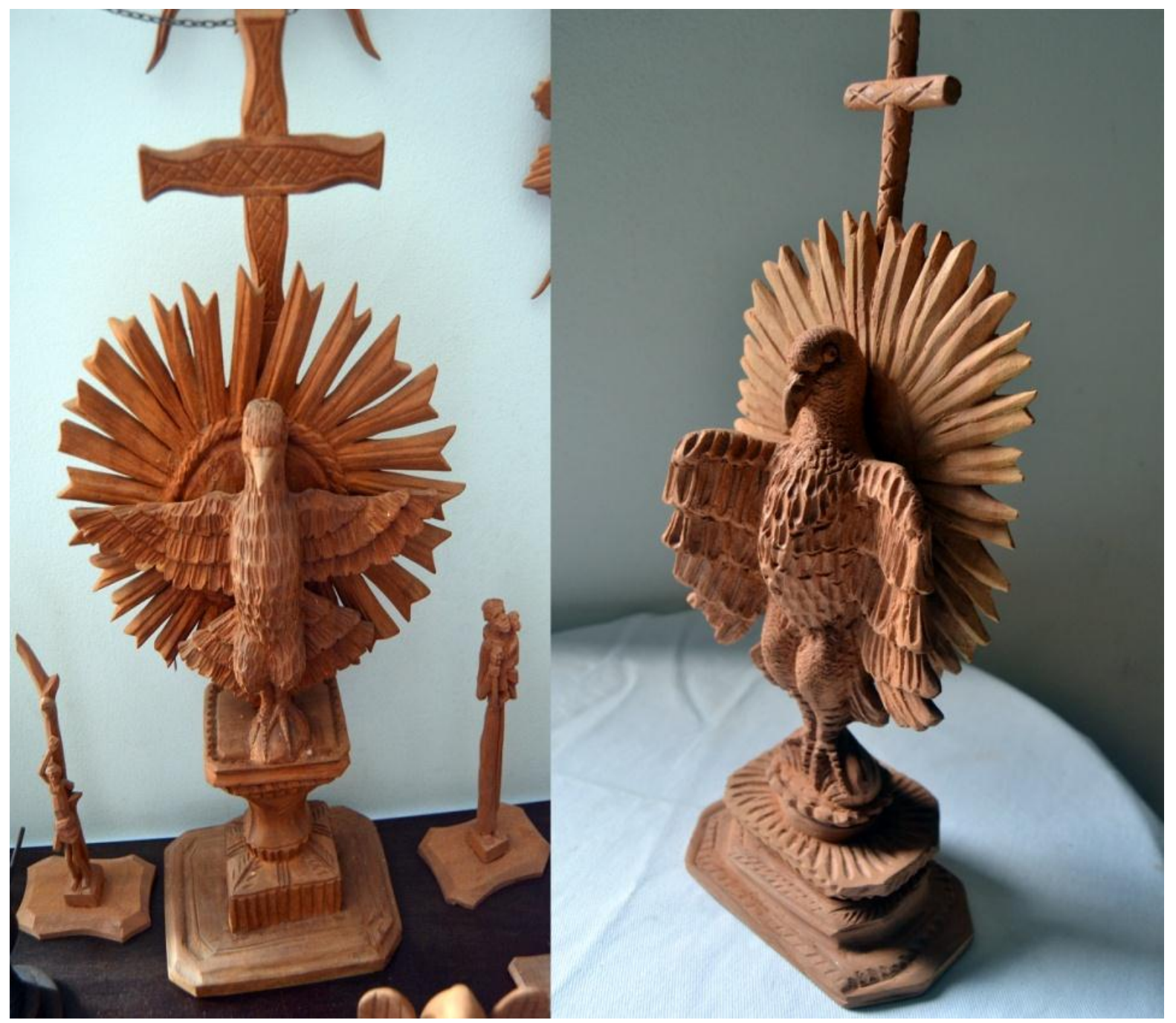

Fig. 14-15. El Santo Espíritu Santo, tallado por Luzia Dantas, $25 \mathrm{~cm}$. madera de umburana. El culto a la tercera persona de la Trinidad, traído por los portugueses, tiene una importancia capital en el calendario religioso brasileño. El volumen y carácter de estas piezas atemorizantes está más cerca de una representación gnóstica de Abraxas que de la pureza e inocencia que destilan otras representaciones canónicas. Si contemplamos los textos de Joaquín de Fiore podríamos estar en estos momentos en la "Edad del Espíritu Santo", un momento para vivir el fenómeno religioso de forma individual, a diferencia de "Edad del Padre" que va desde los inicios a la venida de Cristo, y la "Edad del Hijo", presidida y manejada por los sacerdotes.

\section{Una historia con moraleja a modo de conclusión}

Para terminar este recorrido parcial y limitado voy a narrar una historia verídica que me contó el erudito y restaurador nordestino Hélio de Oliveira. Su condición de experto en la imaginería barroca portuguesa hizo que un exgobernador del estado, cuyo nombre obviamos, le hiciera llamar cuando completó la que él creía que sería la mejor y mayor colección de arte barroco europeo de todo Brasil. Después de que Hélio hubo examinado a conciencia todas y cada una de las piezas del acervo, el experto se dirigió a su anfitrión con la conocida fórmula de: "señor, tengo dos noticias para usted, una mala y otra buena...la mala es que ninguna de estas esculturas que usted posee fueron talladas por artistas 
europeos...y la buena es que el señor es dueño de la mejor colección de imaginería popular del Nordeste".

En conclusión, podemos afirmar que muchos de los defensores del arte popular son sus mayores enemigos. Al marginalizarlo e impedir su evolución se está levantando acta de su obsolescencia. El congelamiento en el tiempo de los elementos pre-lógicos de una comunidad con la coartada de preservar su esencia condena al grupo a convertirse en algo así como un parque temático. En este caso sería un Nordeste barroco, anti-renacentista y anti-moderno, un mundo en el que cualquier novedad es una impertinencia ${ }^{29}$.
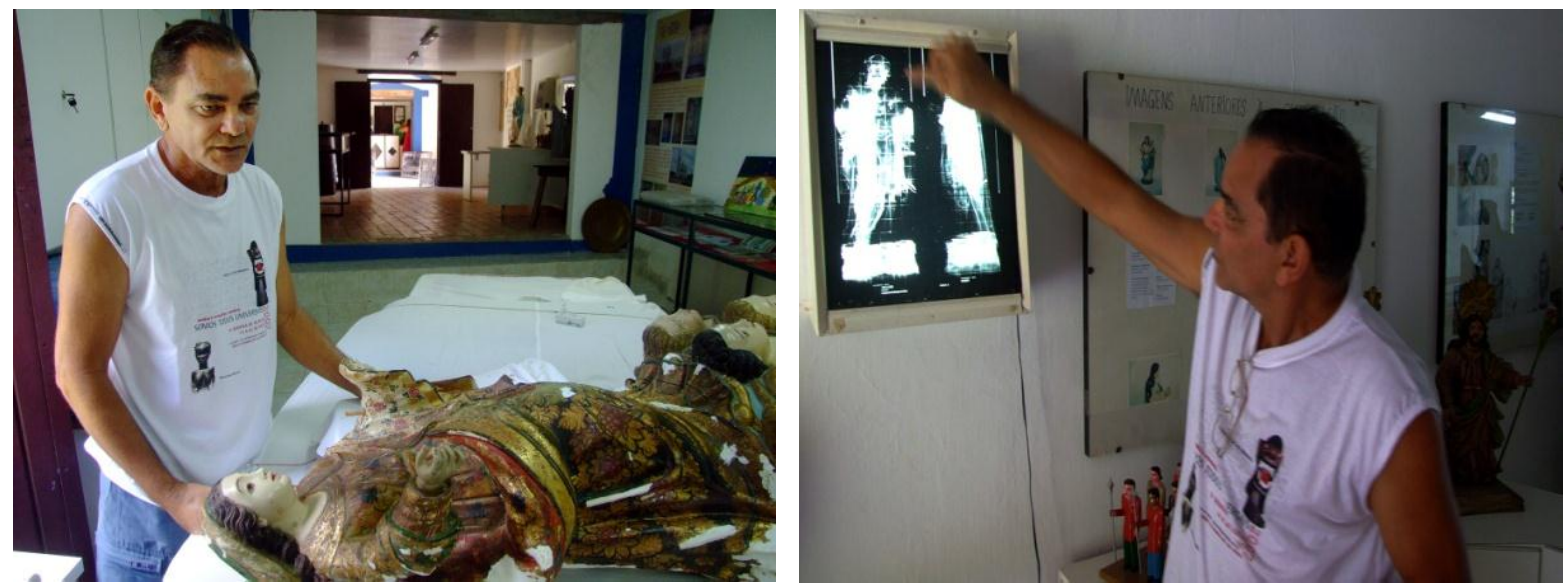

Fig. 16. El restaurador y erudito Hélio de Oliveira, en su taller de "Villa Feliz", Pium, restaurando la imagen de Nuestra Señora de los Imposibles.

\section{NOTAS}

\footnotetext{
${ }^{1}$ HOELLER, Stephan A., Jung gnóstico y los Siete Sermones a los Muerto, Málaga, Sirio, 2005, p. 105.

${ }^{2}$ Sertão: concepto geográfico y cultural que define el interior, o mejor dicho los "interiores" brasileños, mucho más aislados y privados de intercambios culturales y comerciales que la franja costera. Todo aquello que se refiere al "sertão" se adjetiva como sertanejo.

${ }^{3}$ BLOM, Philip, El coleccionista apasionado. Una historia íntima, Barcelona, Anagrama, 2012, p. 17.

${ }^{4}$ La umburana, o falso cerezo es una madera blanda y ligera, fácil de tallar y rígida a la vez. Endémica en el Nordeste brasileño, también se usa como remedio para problemas respiratorios y para construir los barriles donde se envejece la cachaça o licor de caña de azúcar, que podemos considerar bebida nacional de Brasil.

${ }^{5}$ FIGAREDO, Rubén, Por amor al arte. Fragmentos de una enseñanza desconocida, Oviedo, Facultad de Geografía e Historia, 2002, p. 16.

${ }^{6}$ BLOM, Philipp, El coleccionista, óp., cit., p. 152.

${ }^{7}$ HOELLER, Stephan A., Jung y los evangelios perdidos: a propósito de los manuscritos del mar muerto y la biblioteca de nag hammadi, Barcelona, Obelisco, 2005, pp. 25-26.

${ }^{8}$ MENDOÇA, Antonio G., Religiosidade popular e misticismo no Brasil, São Paulo, Edições Paulinas, 1984, p. 12.

9 Término por el cual se conocen a los caciques del medio rural del Nordeste brasileño. Ganaderos, terratenientes, dueños de ingenios azucareros y otros medios de producción, que suplantan el lejano poder gubernamental con un omnímodo poder paralelo.

${ }^{10}$ LÉVI-STRAUSS, Claude, A estrutura dos mitos, en Antropologia Estrutural, Rio de Janeiro, Tempo Brasileiro, 1973, p. 252.
} 


\footnotetext{
${ }^{11}$ MEDEIROS, Bartolomeu, Entre almas, santos e entidades outras no Rio de Janeiro: os mediadores, Rio de Janeiro, Tese de Doutorado apresentada ao Programa de Pós-Graduação em Antropologia Social do Museu Nacional - UFRJ, 1995, p. 248.

${ }^{12}$ MACHADO, María Augusta, São Jorge. Arquétipo, Santo e Orixá, Rio de Janeiro, Ibis Libris, 2008, p. 72.

${ }^{13}$ FREYRE, Gilberto, Escravo, animal e máquina, en Sobrados e mucambos, Rio de Janeiro/São Paulo, Editora Record, 2000, p. 536.

${ }^{14}$ BLOM, Philipp, El coleccionista, óp., cit., p. 158.

${ }^{15}$ Término derivado del griego que designa el proceso evolutivo que es auto-creativo y auto-organizativo.

${ }^{16} \mathrm{BOFF}$, Leonardo, O despertar da águia: o dia-bólico e o sim-bólico na construção da realidade, Petrópolis, Vozes, 2009, p. 45.

${ }^{17}$ Revista Época, Editorial Globo, São Paulo, 5 de agosto, 2005.

${ }^{18}$ STEINER, George, Nostalgia del Absoluto, Siruela, Madrid, 2008, p. 17.

${ }^{19}$ STEINER, George, Nostalgia, óp., cit., p. 22.

${ }^{20} \mathrm{BOFF}$, Leonardo, $O$ despertar da águia, óp., cit., p. 5.

${ }^{21}$ STEINER, George, Nostalgia, óp., cit., p. 128.

${ }^{22}$ STEINER, George, Nostalgia, óp., cit., p.120.

${ }^{23}$ BARROS GUIMARÃES, Leda María de, Arte e Cultura Popular: variações em torno da construção de conceitos e valores, São Paulo, Arteduca, p. 2.

${ }^{24}$ BARROS GUIMARÃES, Leda María de, Arte e Cultura Popular, óp., cit., p. 19.

${ }^{25}$ SALDANHA, Nuno, Arte popular, Arte erudita e multiculturalidade. Influências, confluências e transculturalidade na arte portuguesa, p. 108. Recurso electrónico, consultado el 20 de diciembre del 2016.

${ }^{26}$ STEINER, George, Nostalgia, óp., cit., p. 78.

${ }^{27}$ FOUCAULT, Michael, Foucault Live, Nueva York, Semiotext(e), 1989, p. 269.

${ }^{28}$ LAMBLIN, Bernard, Peinture et Temps, Paris, Meridiens Klincksieck, 1987, p. 550. Traducción del autor.

${ }^{29}$ ALBUQUERQUE JÚNIOR, Durval Muniz de, A invenção do Nordeste e outras artes, São Paulo, Cortez, 2011, p. 223.
}

Fecha de recepción: 15 de octubre de 2016

Fecha de revisión: 5 de enero de 2017

Fecha de aceptación: 20 de enero de 2017 